\title{
Enrichment of Some Heavy Metals With Cloud Point Extraction via 5,7-Diiodo-8-Hydroxyquinoline Ligand and Detection by Ultrasonic Nebulizer-ICP-OES Using Internal Standard Method
}

\author{
Mustafa Sahin Dundar*, Ferhat Kaptan, Celal Caner, and Huseyin Altundag \\ Sakarya University, Faculty of Arts and Sciences, Department of Chemistry, \\ 54187 Sakarya, Turkey
}

\section{INTRODUCTION}

The determination of heavy metals in food and water samples at trace levels is crucial because of their effects on human health and the environment (1). Several techniques commonly used for heavy metal analysis in water include flame atomic absorption spectrometry (FAAS) (2-5), electrothermal atomization atomic absorption spectrometry (ETAAS) (8-13), and inductively coupled plasma-optical emission spectrometry (ICP-OES) (6-7, 14-17). ICP-OES is an efficient technique to determine inorganic elements in environmental and biological samples, and has the ability of multi-element analysis and a high rate analytical efficiency. However, this technique presents reasonable measurability but requires a preconcentration process for metals determination (18).

Metal ion levels are very low in the samples and detection is quite difficult because of the complex ingredients of the matrix. For that reason, pre-concentration and separation technologies (19-21) are used to extract these metals at proper concentrations. These techniques are liquid-liquid extraction $(22,23)$, solid phase extraction (24-26), coprecipitation (27-29), electrochemical accumulation $(30,31)$, ion exchange $(32,33)$, and cloud point extraction (CPE) (34-38). Cloud point extraction is preferred because it is simple, fast, high yield-

*Corresponding author.

E-mail:dundar@sakarya.edu.tr

Tel: +902642956044

Fax: +902642955950

\section{ABSTRACT}

In this study, a method was developed in which the heavy metal ions of $\mathrm{Cu}^{+2}, \mathrm{Cd}^{+2}, \mathrm{Co}^{+2}$, $\mathrm{Ni}^{+2}, \mathrm{~Pb}^{+2}, \mathrm{Zn}^{+2}$ in water samples are enriched by using cloud point extraction and detection using ultrasonic nebulization with inductively coupled plasma optical emission spectrometry (USN-ICP-OES). The metal ions, complexed with the Triton $\mathrm{X}$ 114 surfactant, were imprisoned in the mycelium after phase separation via the centrifuge. The surfactant phase was diluted with $2 \mathrm{M} \mathrm{HNO}_{3}$ and measured by USN-ICP-OES. In order to reduce noise and errors, indium was used as the internal standard. The $\mathrm{pH}$, surfactant concentration, ligand concentration, equilibration time, temperature, and foreign ion effects were investigated. The limit of detection of $\mathrm{Cu}^{+2}, \mathrm{Zn}^{+2}, \mathrm{Ni}^{+2}, \mathrm{Cd}^{+2}, \mathrm{Co}^{+2}, \mathrm{~Pb}^{+2}$ usingt $\mathrm{pH}=7,0.1 \mathrm{mmol} \mathrm{L}^{-1} 5,7$ diiodo-8-hydroxyquinoline, and $\% 0.06(w / v)$ Triton X-114 were found to be $0.076,0.30,0,081$, $0.022,0.033$, and $0.049 \mu \mathrm{g} \mathrm{L}^{-1}$, respectively. The RSD\% was between $2.08 \%$ and $6.28 \%$ $(n=10)$. The developed method is in accordance within green chemistry and was successfully applied to certified reference materials and real water samples.

ing, requires less toxic organic solvents and is, therefore, in compliance with the green chemistry principle (39).

Cloud point extraction is based on phase separation in aqueous solution of non-ionic surface activated agents. Phase separation occurs when the cloud point temperature has been reached, and phase separation may be observed not only with a temperature change but also with any material added or a pressure change. Most non-ionic surface-activated agents may form mycelium and separate into two phases: (a) the phase which is below the critical mycelium concentration or at equal concentration and (b) the surface-activated rich phase which pre-concentrates the analyte ions $(40,41)$. Metal ion complexes are created with the hydrophobic ligand of the surfaceactive rich phase environment and are separated by the other phase by staying in the mycelium created by the surface-activated material (42).

The internal standard method was used in order to balance nonspectral interferences, decrease the noise and to eliminate the multiple errors in the ICP devices. This method is based on measurement and calculation of the reference element comparative to its signal instead of measuring the emission of the analyte $(43,44)$.

In this study, pre-concentration and determination of the $\mathrm{Cu}^{2+}$, $\mathrm{Cd}^{2+}, \mathrm{Pb}^{2+}, \mathrm{Co}^{2+}, \mathrm{Ni}^{2+}$, and $\mathrm{Zn}^{2+}$ ions are performed by using the indium internal standard and ICP-OES with the cloud point extraction method and an ultrasonic nebulizer. The ultrasonic nebulizer increases the analytical capacity due to the higher vapor efficiency. The aerosol formation is more efficient at making small droplets and removes the solvent, thus giving a 10 times better detection limit ( 45 , 46). The complexing agent 5,7diiodo-8-hydroxyquinoline was 
used with Triton ${ }^{\circledR}$ X-114 as the surface-activated agent. The method was applied to the analysis of certified reference material and real water samples.

\section{EXPERIMENTAL}

\section{Instrumentation}

A model Spectro Arcos ICP-OES (Spectro Arcos, Germany) was used to determine the metal concentrations and was equipped with a CETAC U-5000AT+ ultrasonic nebulizer. The optimum instrumental conditions are listed in Table I. The $\mathrm{pH}$ measurements were performed using the Orion 2-Star Plus pH meter (Thermo Scientific, USA) and a NF 400 centrifugation system (Nüve Co., Turkey). A Milli-Q ${ }^{\circledR}$ $\left(18.2 \mathrm{M} \Omega \cdot \mathrm{cm}^{-1}\right)$ Integral Water Purification System was used to produce distilled de-ionized ultrapurified water (Millipore Corporation, USA).

\section{Reagents and Standard Solutions}

All chemicals used were of analytical grade. The metal solutions were prepared with $1000 \mathrm{mg} / \mathrm{L}$ of $\mathrm{Cu}^{2+}, \mathrm{Cd}^{2+}, \mathrm{Pb}^{2+}, \mathrm{Co}^{2+}, \mathrm{Ni}^{2+}$, and $\mathrm{Zn}^{2+}$ standard solutions (Merck, Germany). Adjustment of the solutions to the proper $\mathrm{pH}$ was performed with $0.1 \mathrm{M} \mathrm{NaOH}$ and $0.1 \mathrm{M} \mathrm{HCl}$ (Merck) solutions, then the proper buffers were added. The hydrophobic complexing agent of 5,7-diiodo-8-hydroxyquinoline was used and 1,1,3,3-tetramethylbuthyl (Triton X-114) as the surface-activated agent with the metal ions. A $5 \mathrm{~g}$ amount of Triton X-114 in analytical purity was dissolved in boiling ultrapure water and the volume of the solution completed to 100 $\mathrm{mL}$, resulting in a $5 \%(\mathrm{w} / \mathrm{v})$ surfactant solution. In order to dilute the surface-active rich phase, ultra-purified $2 \mathrm{~mol} \mathrm{~L}^{-1} \mathrm{HNO}_{3}$ solution (Merck) was used. For the prepara-

TABLE I

ICP-OES and Ultrasonic Nebulizer Operating Conditions

\begin{tabular}{ll}
\hline ICP-OES Spectrometer & \\
\hline Viewing Height & $12 \mathrm{~mm}$ \\
Element Wavelength & $\mathrm{Cd}: 214.438 \mathrm{~nm}$ \\
& $\mathrm{Co:} 228616 \mathrm{~nm}$ \\
& $\mathrm{Cu}: 324.754 \mathrm{~nm}$ \\
& $\mathrm{Ni}: 231.604 \mathrm{~nm}$ \\
& $\mathrm{~Pb}: 220.353 \mathrm{~nm}$ \\
& $\mathrm{Zn:} 213.856 \mathrm{~nm}$ \\
Replicates & 3 \\
RF Power & $1450 \mathrm{~W}$ \\
Spray Chamber & $\mathrm{Cyclonic}$ \\
Nebulizer & $\mathrm{Modified} \mathrm{Cetac} \mathrm{ultrasonic} \mathrm{nebulizer}$ \\
Nebulizer flow & $0.8 \mathrm{~L} / \mathrm{min}$ \\
Plasma Gas Flow & $13 \mathrm{~L} / \mathrm{min}$ \\
Auxiliary Gas Flow & $0.7 \mathrm{~L} / \mathrm{min}$ \\
Sample Aspiration Rate & $2.0 \mathrm{~mL} / \mathrm{min}$ \\
Sample Pump Rate & $25 \mathrm{rpm}$ \\
\hline Ultrasonic Nebulizer Conditions & \\
\hline Desolvation Temperature & $140^{\circ} \mathrm{C}$ \\
Condenser Temperature & $5^{\circ} \mathrm{C}$ \\
\hline
\end{tabular}

tion of the solutions, distilled deionized water (Milli-Q Millipore 18.2 $\mathrm{M} \Omega \cdot \mathrm{cm}-1$ resistance) was used. An internal standard solution was prepared from $1000 \mathrm{mg} / \mathrm{L}$ In (SigmaAldrich) stock solution.

\section{Sampling}

The drinking water and river water samples were obtained in 2015 from the Sakarya river in Adapazari city, Turkey. Polyethylene bottles were used to store the samples which were adjusted to the appropriate $\mathrm{pH}$ with $\mathrm{HNO}_{3}$. Then the samples were filtered with a Millipore nitrocellulose membrane (pore size $0.45 \mathrm{~mm}$ ) and stored at $+4{ }^{\circ} \mathrm{C}$ in a refrigerator to prevent microbial activity.

\section{Cloud Point Extraction Procedure}

In order to perform cloud point extraction, $10^{-2} \mathrm{~mol} \mathrm{~L}^{-1}$ 5,7-diiodo-8hydroxyquinoline, buffer, and 5\% (w/v) Triton X-114 solutions were added to the various analyte solutions in the range of $10-500 \mu \mathrm{g} \mathrm{L}^{-1}$ concentration and diluted to $50 \mathrm{~mL}$. This solution was placed into a water bath at $55^{\circ} \mathrm{C}$ for 20 minutes and centrifuged for 10 minutes at $4000 \mathrm{rpm}$. It was then soaked in the ice bath for 20 minutes to increase the viscosity of the surfaceactive rich phase, and the liquid phase of the solution was removed with a micropipette. Following the cooling procedure and because the surface-active rich phase obtained at the bottom of the test tube is viscose, the separation operation can be easily performed. The indium added into the separated surfaceactive rich phase was diluted with 2 mol L-1 $\mathrm{HNO}_{3}$ solution to $2 \mathrm{~mL}$, and the solution analyzed by USNICP-OES.

\section{RESULTS AND DISCUSSION}

\section{Effect of pH}

Because the $\mathrm{pH}$ is one of the basic parameters in complexation 
reactions, it is the first variable that has to be examined. Scanning was performed between the $\mathrm{pH}$ levels of 2 to 12 , and the proper $\mathrm{pH}$ value was found between 7-8. It was observed that using this $\mathrm{pH}$, the 5,7-diiodo-8-hydroxyquinoline complexing agent creates the highest and efficient complexes with the $\mathrm{Cu}^{2+}, \mathrm{Cd}^{2+}, \mathrm{Pb}^{2+}, \mathrm{Co}^{2+}, \mathrm{Ni}^{2+}$, and $\mathrm{Zn}^{2+}$ metal ions. The reason of inefficient recovery on the lowest $\mathrm{pH}$ values may be due to the decrease in stability of the metal complexes of 5,7-diiodo-8-hydroxyquinoline. Precipitation of the metals with hydroxides may affect recovery at high $\mathrm{pH}$ values. The effect of the $\mathrm{pH}$ on the recovery percentages of the metal ions is shown in Figure 1.

\section{Effect of Ligand Concentration}

Formation of a hydrophobic and high stability complex with metals of the ligands is significant for the performance of the extraction. 5,7-diiodo-8-hydroxyquinolin forms hydrophobic complexes with the metal ions and pre-concentration is performed by imprisoning these complexes in the mycelium.

Because reaction of the metals in the environment of the complexation agent is intended, enough complexation agent is required.

Measurements were performed in the concentrations between 0.02 mmol L ${ }^{-1}$ and $0.4 \mathrm{mmol} \mathrm{L}^{-1}$. Recovery values were found to be appropriate at concentrations of 0.08 $\mathrm{mmol} \mathrm{L}^{-1}$ and above. The possible reason is the increase in complexation efficiency of the excessive ligand molecules and simplification of entrance to the mycelium. The effect of ligand concentration on recovery percentages of the metal ions is shown in Figure 2.

\section{Effect of Triton X-114}

Triton X-114 was selected as the surface-activated agent because of high density during phase separa- tion and use of lower mycelium temperature $\left(23-26^{\circ} \mathrm{C}\right)$. The Triton $\mathrm{X}-114$ surface-activated agent was tested between the concentration range of $0.005-0.2 \%(\mathrm{w} / \mathrm{v})$ which gives the highest recovery rates at $0.04-0.125 \%(\mathrm{w} / \mathrm{v})$ concentration Thus, $0.06 \%(\mathrm{w} / \mathrm{v})$ was chosen as the optimum rate. The effect of the recycling percentage of the metal ions on the surface-activated agent concentration is shown in Figure 3.

\section{Effect of Equilibration Time and Temperature}

In order to form stable hydrophobic complexes in cloud point

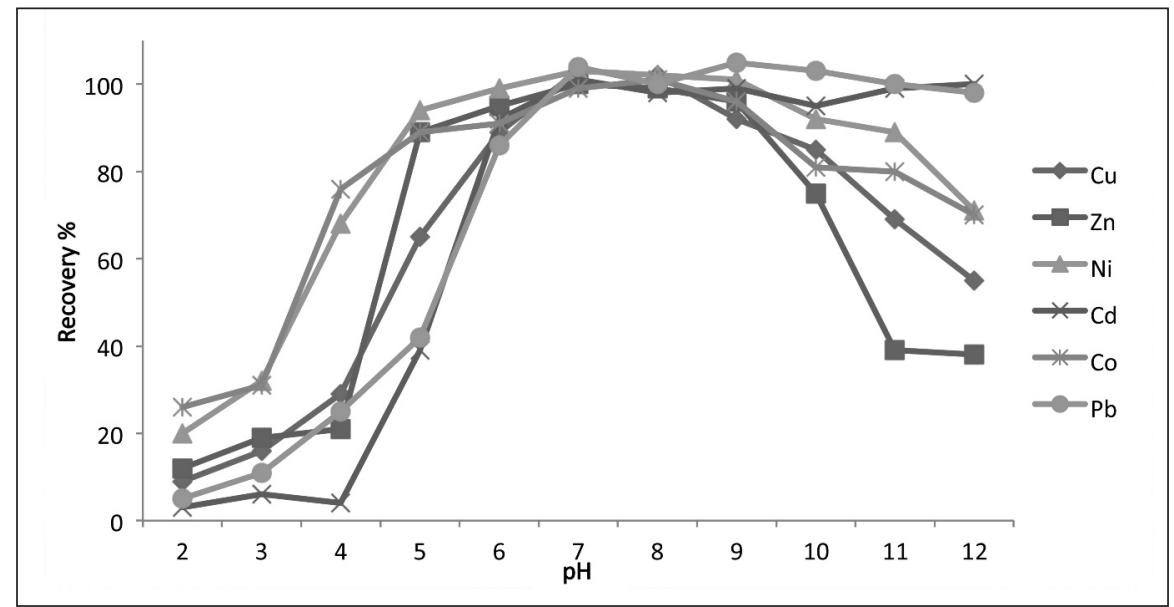

Fig. 1. Effect of $p H$ on the recoveries of the metal ions. Conditions: $50 \mathrm{~mL}$ solution,

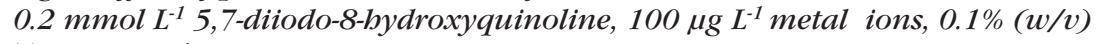
Triton $X-114$.

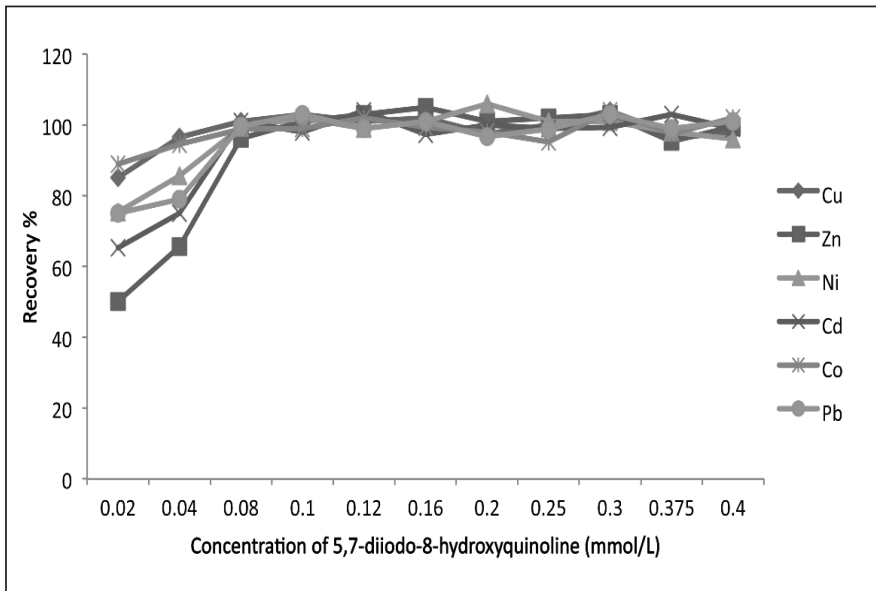

Fig. 2. Effect of complexing agent concentration on the recoveries of the metal ions. Conditions: $50 \mathrm{~mL}$ solution, $\mathrm{pH} 7.0$, $100 \mu \mathrm{g} \mathrm{L} \mathrm{L}^{-1}$ metal ions, $0.05 \%(w / v)$ Triton $X-114$.

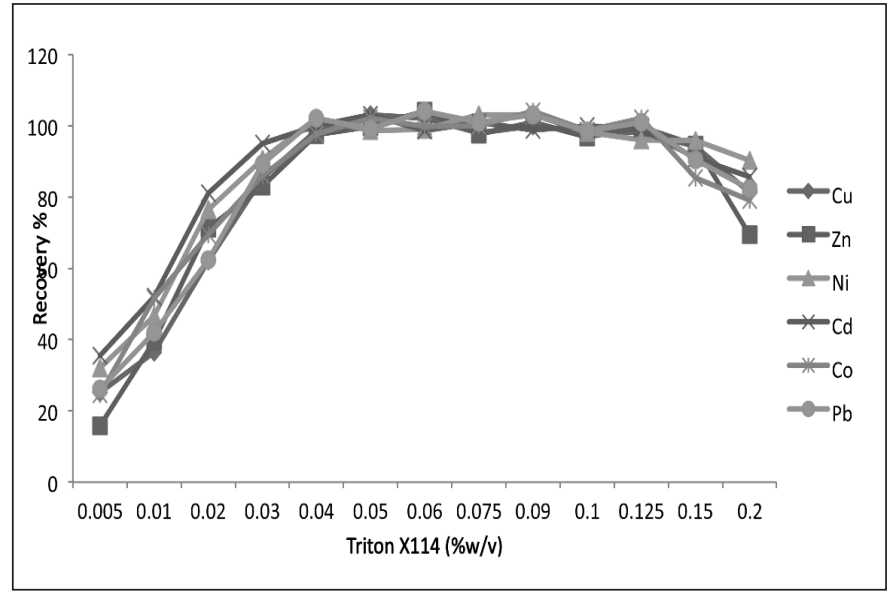

Fig. 3. Effect of Triton $X-114$ concentration on the recoveries of metal ions. Conditions: $50 \mathrm{~mL}$ solution, $0.1 \mathrm{mmol} \mathrm{L}^{-1}, 5$ 7diiodo-8-hydroxyquinoline, $p H$ 7.0, $100 \mu \mathrm{g} \mathrm{L}^{-1}$ metal ions. 
extraction and to imprison the hydrophobic structure complexes with the surface-activated agent, the cloud point temperature has to be reached. Complexation efficiency may decrease at low temperatures or remain below the critical concentration of the surface-activated agent. Formations may become unstable at higher temperatures. In this study, it was observed that the recovery value is good for 15 minutes or above and between 45-60 ${ }^{\circ} \mathrm{C}$. Thus, 20 minutes with $50{ }^{\circ} \mathrm{C}$ was the accepted optimum value.

\section{Effect of Interfering Ions}

Because of the reasons stated in the previous section, a common ion effect study was performed in order to obtain at least $95 \%$ recovery during the enrichment of the metal ions in the presence of various anions and cations. While conducting the experiment, common ion solutions at various concentrations were added to $100 \mathrm{ng} \mathrm{mL}^{-1}$ concentrationof the metal ions and cloud point extraction was tested. No undesired interferences were observed up to the specified values as are listed in Table II.

\section{Analytical Performance}

After the optimum conditions of the proposed method were

TABLE II Effect of Matrix Ions

\begin{tabular}{lc}
\hline Ions & Tolerance Limit \\
\hline $\mathrm{Na}^{+}$ & $5000: 1$ \\
$\mathrm{~K}^{+}$ & $5000: 1$ \\
$\mathrm{Mg}^{2+}$ & $2000: 1$ \\
$\mathrm{Ca}^{2+}$ & $1000: 1$ \\
$\mathrm{Al}^{3+}$ & $100: 1$ \\
$\mathrm{Ba}^{2+}$ & $10: 1$ \\
$\mathrm{Fe}^{3+}$ & $5: 1$ \\
$\mathrm{Cl}^{-}$ & $5000: 1$ \\
$\mathrm{NO}_{3}{ }^{-}$ & $5000: 1$ \\
$\mathrm{~F}^{-}$ & $5000: 1$ \\
$\mathrm{SO}_{4}{ }^{2-}$ & $500: 1$ \\
\hline
\end{tabular}

obtained, enrichment factor, limit of quantification, limit of detection and precision were calculated as the analytical performance values. The enrichment factor is calculated as the proportion of the slope of the calibration curve obtained by pre-concentration to the slope of the calibration line without preconcentration. The LOD values are calculated using 3 times the 10 independent blank standard deviation divided by the calibration line slope $(3 \sigma / \mathrm{m})$. The LOQ values are calculated using 10 times the standard deviation of the blanks divided by the calibration line slope of $(10 \sigma / \mathrm{m})$. Other measurements and the results are listed in Table III.

\section{Analysis of Reference Material and Real Water Samples}

Good agreeent of the results of the proposed method was also verified by using the standard reference material (SRM) INCT-TL-1 Tea Leaves (Institute of Nuclear Chemistry and Technology, Poland). For all studies, In was used as the internal standard which was added dur- ing the optimization phase resulting in sample measurements at the final value of $100 \mu \mathrm{g} \mathrm{L}^{-1}$. Excellent recovery of the metals for 500-mL water samles with the cloud point extraction method is demonstrated by using the optimum UN-ICP-OES conditions and the results are listed in Tables IV and V.

\section{CONCLUSION}

A method which allows detection of the heavy metals (copper, cobalt, nickel, lead, and cadmium) at trace levels was evaluated. Indium (In) was used as the internal standard, and the internal standard technique is applied successfully in order to prevent the entrance of noise and various interferences. The ultrasonic nebulizer was mounted to the ICP-OES device and similar detection limits of the metals were obtained. The method was also applied to a certified reference material with successful recovery results between $97.4 \%$ and $102.7 \%$. Heavy metal ions $\left(\mathrm{Cu}^{+2}, \mathrm{Zn}^{+2}, \mathrm{Ni}^{+2}\right.$, $\left.\mathrm{Cd}^{+2}, \mathrm{Co}^{+2}, \mathrm{~Pb}^{+2}\right)$ in water samples

TABLE III

Analytical Performance Parameters of the Proposed Method

\begin{tabular}{|c|c|c|c|c|c|c|}
\hline Parameters & $\mathrm{Cu}$ & $\mathrm{Zn}$ & $\mathrm{Ni}$ & $\mathrm{Cd}$ & Co & $\mathrm{Pb}$ \\
\hline Enrichment Factor & 21.04 & 18.79 & 21.85 & 21.73 & 14.06 & 13.33 \\
\hline Correlation Coefficient* & 0.9984 & 0.9885 & 0.9977 & 0.9987 & 0.9985 & 0.9980 \\
\hline $\operatorname{RSD}(n=10)$ & 3.63 & 6.28 & 2.08 & 2.11 & 3.45 & 3.87 \\
\hline LOQ (ng mL $\mathrm{mL}^{-1}$ ) & 0.250 & 0.99 & 0.27 & 0.076 & 0,1 & 0,16 \\
\hline $\mathrm{LOD}\left(\mathrm{ng} \mathrm{mL}^{-1}\right)$ & 0.076 & 0.30 & 0.081 & 0.022 & 0.033 & 0.049 \\
\hline
\end{tabular}

${ }^{\mathrm{a} C}$ Correlation coefficient after CPE.

TABLE IV

Analysis of Certified Reference Material for the Determination of Analytes After Application (n=3)

\begin{tabular}{cccc}
\hline Ions & $\begin{array}{c}\text { Certified Values } \\
\left(\mu \mathrm{g} \mathrm{g}^{-1}\right)\end{array}$ & $\begin{array}{c}\text { Values of Present Study } \\
\left(\mu \mathrm{g} \mathrm{g}^{-1}\right)\end{array}$ & $\begin{array}{c}\text { Recovery } \\
(\%)\end{array}$ \\
\hline $\mathrm{Cu}$ & $20.400 \pm 1.500$ & $20.920 \pm 0.460$ & 102.7 \\
$\mathrm{Zn}$ & $34.700 \pm 2.700$ & $33.900 \pm 2.960$ & 97.7 \\
$\mathrm{Ni}$ & $6.120 \pm 0.520$ & $5.960 \pm 0.960$ & 97.4 \\
$\mathrm{Cd}$ & $0.030 \pm 0.004$ & $0.032 \pm 0.003$ & 106.6 \\
$\mathrm{Co}$ & $0.387 \pm 0.042$ & $0.385 \pm 0.031$ & 99.5 \\
$\mathrm{~Pb}$ & $1.780 \pm 0.240$ & $1.733 \pm 0.180$ & 97.4 \\
\hline
\end{tabular}




\section{Atomic Apectroscopy \\ 1 Vol. 39(6), Nov./Dec. 2018}

TABLE $\mathrm{V}$

Recovery of Metals in Water Samples $(n=3)$

Sample

Ions Added Measured Recovery $(\mu \mathrm{g} \mathrm{L}-1) \quad(\mu \mathrm{g} \mathrm{L}-1) \quad(\%)$

\section{Tap Water}

$\mathrm{Cu} \quad 0 \quad 0.48$

$5 \quad 5.45$

99.0

$\begin{array}{lll}10 & 10.72 \quad 102.4\end{array}$

Zn $0 \quad 1.12$

$\begin{array}{lll}5 & 6.27 & 103.0\end{array}$

$10 \quad 11.74 \quad 106.0$

Ni $0 \quad$ BDL

$\begin{array}{lll}5 & 4.9 & 98.0\end{array}$

$\begin{array}{lll}10 & 10.22 \quad 102.0\end{array}$

Cd $0 \quad$ BDL

$\begin{array}{lll}5 & 5.05 & 101.0\end{array}$

$\begin{array}{lll}10 & 9.94 \quad 99.0\end{array}$

Co 0 BDL

$\begin{array}{lll}5 & 4.82 & 96.0\end{array}$

$\begin{array}{lll}10 \quad 10.18 & 102.0\end{array}$

$\mathrm{Pb} 0$ BDL

$\begin{array}{lll}5 & 5.23 & 105.0\end{array}$

$\begin{array}{lll}10 & 10.32 \quad 103.0\end{array}$

\section{River Water}

\begin{tabular}{|c|c|c|}
\hline $\mathrm{Cu}$ & 1.62 & \\
\hline 5 & 6.69 & 101.0 \\
\hline 10 & 11.91 & 103.0 \\
\hline $\mathrm{Zn}$ & 3.22 & \\
\hline 5 & 8.43 & 104.0 \\
\hline 10 & 13.9 & 107.0 \\
\hline 0 & 0.57 & \\
\hline 5 & 5.61 & 101.0 \\
\hline 10 & 10,23 & 97.0 \\
\hline 0 & BDL & \\
\hline 5 & 4.86 & 97.0 \\
\hline 10 & 9.77 & 98.0 \\
\hline 0 & $\mathrm{BDL}$ & \\
\hline 5 & 5.31 & 106.0 \\
\hline 10 & 9.78 & 98.0 \\
\hline 0 & $\mathrm{BDL}$ & \\
\hline 5 & 5.19 & 104.0 \\
\hline 10 & 10.07 & 101.0 \\
\hline
\end{tabular}

BDL : Below detection limit. are enriched by using cloud point extraction and at optimum conditions the limit of detection of the metals were found at $0.076,0.30$, 0,081, 0.022, 0.033, and 0.049 $\mu \mathrm{g} \mathrm{L}^{-1}$, respectively. Also, an enrichment factor between 13.33 and 21.85 was obtained. This study shows a method which can perform metals detection in accordance with the green chemistry concept by eliminating the harmful use of chemicals. In addition, the method is fast, simple, efficient, and low cost for use in the determination of heavy metals at the $\mu \mathrm{g} \mathrm{\textrm {L } ^ { - 1 }}$ levels.

Received January 17, 2018.

\section{REFERENCES}

1. H. Altundag, S. Albayrak, M. S. Dundar, M. Tuzen, and M. Soylak, At. Spectrosc. 34(2), 159 (2015).

2. S. Candir, I. Narin, and M. Soylak, Talanta 77, 289 (2008).

3. V. A. Lemos, J. S. Santos, and P.X.J. Baliza, Braz. Chem. Soc. 17, 30 (2006).

4. H. Altundag, M. S. Dundar, S. Doganci, M. Celik, and M. Tuzen, J. AOAC Int. 96(1), 166 (2013).

5. Z. F. Fan, Microchim. Acta 15229 (2005).

6. J. H. Wang, E. H. Hassen, and B. Gammelgard, Talanta 55117 (2001).

7. M. A. M. Silva, V. L. A. Frescura, and A. J. Curtius, Spectrochim. Acta Part B 56(10), 1941 (2001).

8. X. S. Zhu, X. H. Zhu, and B. S. Wang, Microchim. Acta 15495 (2006).

9. T. A. Maranhao, D. L. G. Borges, M. A. M. L. Veiga, and A. J. Curtius, Spectrochim. Acta Part B 60(5), 667 (2005).

10. H. B. Sang, P. Liang, and D. J. Du, J. Hazard. Mater. 154, 1127 (2008).

11. F. Shemirani, M. Baghdadi, M. Ramezani, and M. R. Jamali, Anal. Chim. Acta 534, 163 (2005).

12. D. L. G. Borges, M. A. M. S. Veiga,
V. A. L. Frescura, B. Welz, and A. J. Curtius, J. Anal. At. Spectrom. 18, 501 (2003).

13. F. Shemirani, M. Baghdadi, and M. Ramezani, Talanta 65, 882 (2005).

14. N. Ozcan, and H. Altundag, B. Chem. Soc. Ethiopia 27(2), 205 (2013).

15. Y. J. Li, and B. Hu, J. Hazard. Mater. 174, 534 (2010).

16. H. Altundag, Fresen. Environ. Bull. 24(12a), 4452 (2015).

17. S. Shariati, Y. Yamini, and M. K. Zanjani, J. Hazard. Mater. 156, 5833 (2008).

18. C. R. T. Tarley, S. L. C. Ferreira, and M. A. Z. Arruda, Microchem. J. 77,163 (2004)

19. M. Ghaedi, F. Ahmadi, and M. Soylak, J. Hazard. Mater. 147, 226 (2007).

20. M. Ghaedi, F. Ahmadi, and A Shokrollahi, J. Hazard. Mater. 142, 1158 (2007).

21. M. Ghaedi, F. Ahmadi, Z. Tavakoli, M. Montazerozohori, A. Khanmohammadi, and M. Soylak, J. Hazard. Mater. 152, 1248 (2008).

22. T. Wanga, C. Lia, K. Sakanishia, T. Nakazatob, H. Taob, T. Takanohashia, T. Takaradac, and I. Saitoa, Fuel. 84, 1487 (2005).

23. Y. Okamoto, Y. Nomura, H. Nakamura, K. Iwamaru, F. Fujiwara, and T. Kumamaru, Microchem. J. 65, 341 (2000).

24. G. P. C. Rao, S. S. Veni, K. Pratap, Y. K. Rao, and K. Seshaiah, Anal. Lett. 39, 1009 (2006).

25. M. Soylak, and M. Tuzen, J. Hazard. Mater. 137, 1496 (2006).

26. E. Akyuz, M. Imamoglu, and $\mathrm{H}$. Altundag, Atom. Spectrosc. 34(4), 146 (2013).

27. M. Soylak, and N. D. Erdogan, J. Hazard. Mater. 137, 1035 (2006).

28. J. Liu, H. Chen, X. Mao, and X Jin, Int. J. Environ. Anal. Chem. 76, 267 (2000).

29. S. Saracoglu, M. Soylak, D. S. Kacar Peker, L. Elci, W. N. L. dos Santos, V. A. Lemos, and S. L. C. Ferreira, Anal. Chim. Acta 575, 133 (2006).

30. H. Matusiewicz, and M. Lesinski, 
Int. J. Environ. Anal. Chem. 82, 207 (2002).

31. J. Komarek, P. Stavinoha, S. Gomiscek, and L. Sommer, Talanta 43, 1321 (1996).

32. Z. T. Jiang, J. C. Yu, and H. Y. Liu, Anal. Sci. 21, 851 (2005).

33. Z. Fang, J. Ruzicka, and E. H. Hansen, Anal. Chim. Acta 164, 23 (1984).

34. L. Tavakoli, Y. Yamini, H. Ebrahimzadeh, A. Nezhadali, S. Shariati, and F. Nourmohammadi, J. Hazard. Mater. 152, 737 (2008).

35. J. L. Manzoori, H. Abdolmohammad-Zadeh, and M. Amjadi, J. Hazard. Mater. 144, 458 (2007).

36. Z. Fan, and F. Bai, At. Spectrosc. 28, 30 (2007).

37. M. Ghaedi, A. Shokrollahi, K. Niknam, E. Niknam, A. Najibi, and M. Soylak, J. Hazard. Mater. 168, 1022 (2009).

38. W. I. Mortada, A. Z. Ali, and M. M. Hassanien, Anal. Meth. 5, 5234 (2013).

39. A. Anastas, and N. Eghbali, Chem. Soc Rev. 39, 301 (2010).

40. M. Ghaedi, A. Shokrollahi, K. Niknam, E. Niknam, S. Derki, and M. Soylak, J. AOAC Int. 92, 907 (2009).

41. H. Filik, T. Cengel, and R. Apak, J. Hazard. Mater. 169, 766 (2009).

42. C. B. Ojeda, and F. S. Rojas, Anal. Bioanal. Chem. 394, 759 (2009).

43. H. Kola, and P. Peramaki, Spectrochim. Acta Part B 59, 231 (2004).

44. G. A. Zachariadis, and D. C. Vogiatzis, Appl. Spectrosc. Rev. 45, 220 (2010).

45. M. A. M. Silva, V. L. A. Frescura, and A. J. Curtius, Spectrochim. Acta Part B 55, 803 (2000).

46. R. I. Botto, J. Anal. Atom. Spectrom. 8, 51 (1993). 